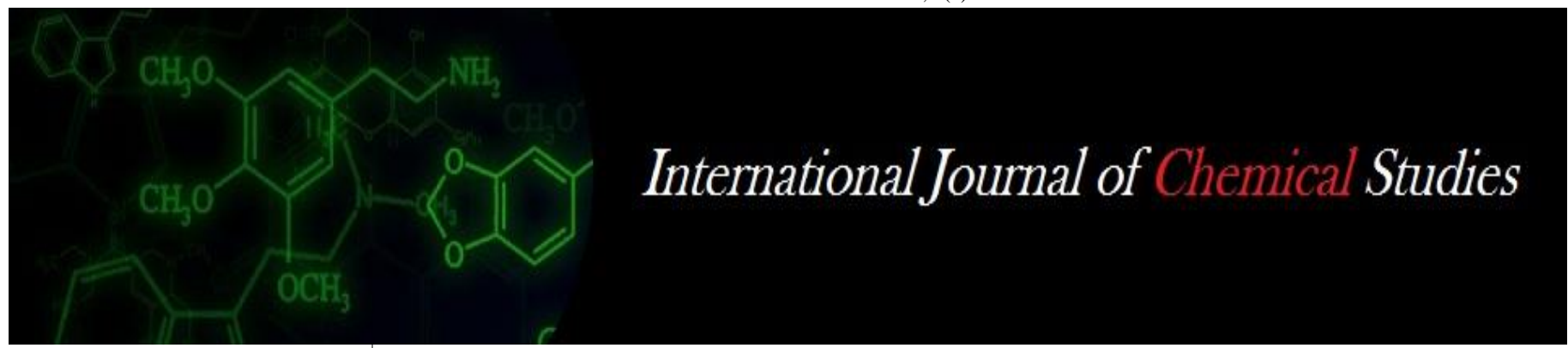

P-ISSN: 2349-8528

E-ISSN: 2321-4902

www.chemijournal.com

IJCS 2020; 8(2): 993-998

(C) 2020 IJCS

Received: 25-01-2020

Accepted: 27-02-2020

Rupashree Senapati

Centurion University of

Technology and

Management, Odisha,

India

Nandini Padhi

Centurion University of

Technology and

Management, Odisha,

India

\section{Assessment of challenges and potential factors of OUAT students for farm-entrepreneurship development}

\section{Rupashree Senapati and Nandini Padhi}

DOI: https://doi.org/10.22271/chemi.2020.v8.i20.8897

\section{Abstract}

A study was conducted with the Agriculture and Veterinary post graduates and $\mathrm{PhD}$ students for identification of entrepreneurial skills in them at Orissa University of Agriculture and Technology (OUAT). SWOT analysis was the method applied for recognising the influencing factors that may help in developing a collaborative approach between priority preferences and entrepreneurial abilities regarding Strength, Weakness, Opportunity and Threat. Here in this study we found that Rural Agricultural Work Experience, Practical feasibility of many courses, Micro-enterprises as initiatives etc were found as strength and opportunities or positive influencing factors while Less emphasis on entreprenurship in course curriculum, Orienatation of society towards job security, Marketing strategy etc. were amongst the negative factors under Weaknesses and Threats along with many other factors. We went further extent of endorsement of factors through a frequency table mentioned here as recognised by the sample as their positive or negative abilities.

Keywords: Challenges, potential factors, OUAT students

\section{Introduction}

In the developing countries, such as India, most of the new jobs are created by unorganised sectors. Both in developed and developing countries, cultures and creativities play risk. Structural policy and supporting education are the foundation for growth and prosperity of entrepreneurship activities. The main problem until now is the majority of students as young people still have a mind that they must seek a job. They also get support from their parents who want their children to choose work rather than entrepreneurship.

It may be because people still believe that education should

Agung in Napitupulu (2012) ${ }^{[8]}$ has said that it occurs partly because people still shackled the idea that education should end up working in a national or multinational company.

Each institution has a different focus that contributes to the growth of sustainable and maturation of entrepreneurship as a general course, in which it gives effect to contribute directly to economic productivity and jobs. Currently, the Private Universities offers a variety of courses to attract students that course is related to the business.

\section{Objectives}

- To analyze the socio-economic background of students relating to entrepreneurship aspects.

- To identify the influencing factors under Strength, Weakness, Opportunity and Threat dimensions in agricultural education with entrepreneurship making and a finding the facts behind the ideas.

- To prepare a frequency table for endorsement of factors as recognised by the sample as their positive or negative abilities.

\section{Methodology}

Students with higher qualifications (generally post-graduate and $\mathrm{PhD}$ ) were taken as respondents. Here this research methodology was implemented for a simple descriptive analysis of economic, technical, sociological and managerial activities that characterize the entrepreneurial abilities those identify the strengths, weaknesses, opportunities, threats.
Corresponding Author: Rupashree Senapati Technology and Management, Odisha, India 
Again through focussed group discussion we tried to analyse the causes and also made some recommendations to eliminate or minimize negative aspects and or recovery of the positive outcomes. SWOT analysis is a tool by which the necessary information can be analyzed to develop competitive analysis.

In SWOT analysis Strength and weaknesses are considered as internal factors while opportunity and threat are considered as external factors.

Data were collected from OUAT students in early 2017 when its around six months past from any admission procedure and students have gained some knowledge / vision regarding their future career prospects.

A sample of 50 students were taken into account and data were collected through questionnaire method with cooperation from experts of the University. Focussed group approach was also another approach of study during data collection as per the need of the hour.

\section{Findings \& discussion}

\section{Socio-economic background of students}

As from the socio-economic status of students data were collected from 58\% Post Graduate students and $46 \% \mathrm{PhD}$ students. Amongst them $68 \%$ are having only one earning member in the family and only $32 \%$ respondents were having more than one member who can earn in their family. Amongst the sample size of 50, 45\% sample have their father as Govt. Servants and $26 \%$ are in Private service and the rest $28 \%$ being in business or farming activities. $66 \%$ students come from a nuclear family whereas $34 \%$ students belong to joint family. Around 76\% respondents' family income remain within 5 to 10 lakhs whereas $24 \%$ family earn more than that as their annual income.

\section{SWOT Analysis}

These are the factors identified under Strength, Weakness, Opportunity and Threat category.

\section{Strength}

\section{Rural Agricultural Work Experience}

People from agriculture background get exposed to rural field during practical studies. Along with this they also have to experience an educational trip for around 4 to 6 months as RAWE programme. (Now READY programme) Veterinary students also do internships in their last semester. This gives these people an edge over others to gain an insight in to the real situation which helps for pragmatic approach for entrepreneurship development.

It helps in choosing the right locality and develop a linkage.

\section{Selected through Entrance Exam}

All the students who have got an admission in OUAT had to pass through a tough entrance examination which already bears a proof of their merit. Even for post graduation and $\mathrm{PhD}$ degrees also they have to clear entrance exam to get a merit seat.

OUAT till date being single Government University in this state, students face a tough competition to get entry in to it.

After doing such a technical course from such reputed institution it becomes a confidence boosting factor for them to start working as entrepreneur from the related subjects with greater capacity building. Dealing with the subjects becomes easy knowing closely the loopholes and reasons of related phenomena.

\section{Understanding the latest issues of agriculture}

Agriculture/ Veterinary are the subjects in OUAT where only students from science background during their intermediate period can get admission through. But agriculture is considered as both arts and science as studied by them in their $1^{\text {st }}$ semester. They study a variety of subjects including Agronomy, Soil science, Entomology, Horticulture, Agril. Extension, Agril. Economics etc. Therefore they can get at least a bird's eye view in almost all relevant subjects for competition. Again course curriculum is designed in such a way for students to get abreast of the latest knowledge especially during Post Graduate and $\mathrm{PhD}$ studies.

\section{Practical feasibility of many courses}

Poultry, Diary, fishery are very much profit making options for entrepreneurship with medium level investments relating to veterinary discipline. Courses like Entomology (apiary, sericulture as entrepreneurship options), Floriculture (cultivation of high value flowers like Gerbera, tuberose etc.), Plant Pathology (Mushroom cultivation), Fruit science and Vegetable science are providing viable and lucrative entrepreneurship options.

\section{Weakness}

\section{Theoretical course work}

Though they studied agriculture subject as a technical course but there was a lacunae of linkage between field application and theory. The RAWE (Rural Agriculture Work Experience) was a practical course work of six months for B.Sc. (Agriculture) courses which was implemented during last semester. After which the students got post-graduation only in their specialised courses. So they had less opportunities to gain practical knowledge.

\section{Less emphasis on entrepreneurship in course curriculum} Though there are many feasible courses for making entrepreneurship and courses like Entomology (apiculture, sericulture as entrepreneurship options), Floriculture (cultivation of high value flowers), Plant Pathology (Mushroom cultivation), Fruit science and Vegetable science are providing viable and lucrative entrepreneurship options, but there is no direct course work related to entrepreneurship except in Agricultural Extension (one full time course related to entrepreneurship) in post graduation. Students from Agricultural background studied a course named "Entrepreneurship development Entrepreneurship skills"(1+1 credit hour) during 3rd year of graduation and students from Veterinary background studied "Livestock Entrepreneurship" $(1+0$ credit hour) during 5th year of B.V.Sc.

\section{Capital}

Entrepreneuship needs initial investment. Students after receiving their degree seek for an income source. Job becomes a need for them due to societal responsibilities and family pressure. Earning a huge amount of money in a short while is not normally possible for them due to lesser scopes for high profile jobs unlike good engineering, IT/Software or MBA Professionals. So capital becomes a scarcity for them in future prospects too, though knowledge, technology and skills they do achieve.

\section{Orientation of society towards job security}

They prefer Govt. jobs as most secured option than any other options. If at all they want some entrepreneurship its after only securing a regular livelihood as the students quoted. Moreover neighbourhood and relatives also expect an immediate job reward following a desirable degree as a good 
student. This creates a pear pressure for preparation for banking, agricultural research services, civil services or any other competitive as lucrative secured options

\section{No family back-up}

Students' socio-economic background showed that most of them have come from middle class to upper middle class families. Therefore family aspirations are oriented towards Government job preferences or at least any type of job rather than business as an option after completion of studies. Emerging trends have the fear of disapproval especially in not a very innovative society. Opting for entrepreneurship after doing higher studies is still a rare example in cult of Odisha. It needs time for diffusion of these ideas.

With whole family approach / principle (family start-ups) it may become an acceptable trend and may lead to success.

\section{Cultural effect}

Cultural effect also do matter because maximum students belong to middle to upper middle class family where generally one or two elder family members earn livelihood through Govt. jobs/ Private jobs or family business units. Unlike Gujarat or Marwari families people don't have strong orientation towards business here.

Emerging trends have the fear of disapproval especially in not a very innovative society. Opting for entrepreneurship after doing higher studies is still a rare example in cult of Odisha. It needs time for diffusion of these ideas. With whole family approach/principle (family start-ups) it may become an acceptable trend and may lead to success.

\section{Interested only in partnership projects and Lacking risk taking ability and faith}

Due to financial risks and other constraints people prefer to be in partnership so that risk features can be mitigated to some extents.

Here risk taking ability is also very less as accompanied their own views regarding entrepreneurship whereas moderate to high risk taking ability is a pre-requisite for successful entrepreneurship development. They felt, it is very tough to recover if financial crisis occurs in a new entrepreneurship business. But with existing other sources of income or family business they may proceed with this option.

\section{Opportunity}

Govt schemes suitability \& Promotion of entrepreneurship projects in agriculture

Governments' new entrepreneurship based schemes like "Make in India", "Skill India", "Stand up India" etc are gaining popularity and huge investments are promoted. This creates an awareness amongst people.

Now a days entrepreneurship has gained importance some extra-mural projects relating to entrepreneurship are going on under ICAR system in some Central level institutions. (e.g. ICAR-CIWA, Bhubaneswar). Recently entrepreneurship incubation centres have been projected in OUAT too. Workshops, Trainings etc related to entrepreneurship aspects are also proceeding in numbers now a days. These things are creating awareness and motivation towards entrepreneurship here.

\section{Credit scheme towards agriculture graduates}

Some banks including NABARD are offering good credit schemes towards people from agriculture study background. Therefore there is an emerging trend that people from good farming background are ready for opting agrri related courses even in Private Universities rather than engineering or other courses for their next generation.

\section{Micro-enterprises as initiatives/ Home stead production units related to agriculture}

These sectors need less investments for initiation as compared to other sectors for making entrepreneurship units. Business can also be started as homestead units at first. These are quite easy to handle. Many surveys show that illiterate farm women have also been successful in dealing with these activities. Though there are many different marketing strategies adopted for tracking customers, here students don't get to study marketing though economics is a major subject here. Still every products from these sectors find huge customer base as these are basic needs of human beings and it does not vary from different hierarchies of society.

\section{Inflation \& Existing Demand}

Food products' price are also in great inflation therefore good profits can be earned through home stead productions too after meeting own family's needs. Therefore these opportunities must be reckoned for success. Some supply chains can be created for larger market produce through good contacts. Agriculture and livestock or poultry related entrepreneurship has the advantage that every household needs these products and on a regular scale. So demand will always be there. But according to the needs of the situation emerging entrepreneurs can add value to the products with changing market demand.

\section{Expert's' advice}

Expert's advice are readily available because the students are always in face to face contact with in specialists and experienced faculties of OUAT and also to some extent access to other central level institutes (ICAR- NRRI, ICARCIWA, ICAR- IIWM etc.) Other Krishi vigyan Kendras, Agriculture Offices and officials. So whenever something goes wrong experts' advice always available and ready contacts are there with greater approach as they are students of OUAT making it an added advantage. They can get examples of some of the past students who are successful entrepreneurs and get contacts of them more conveniently than outsiders. During educational trips these people get exposed to progressive farmers, entrepreneurs that adds an edge over the applicability of their knowledge.

\section{Easy Decision making and finance making}

Any job comes with responsibility and compromising your own independence. And in case of holding ajob you can not always choose job place, own decision making abilities and regular but a moderate level of financial on your own.Sometimes people like to work from home though they are quite hard workers. If you can put incredible amount of work then you also seek reward may be as financial abundance. This option may shrink with any other job rather than entrepreneurship type business activities.

\section{Threat \\ Financial crisis ( Fund/ Credit)}

The data shows that people feel that if they are given opportunities they will become good entrepreneurs but they fear about failure. Here risk taking ability is also very less. They feel it is very tough to recover if financial crisis occurs for a new entrepreneur. But with existing other sources of income or family business they may proceed with this option. 


\section{Technological lacunae}

Though there are many processed food industries, herbal products company, Agri Export industries in our country they don't hire directly agriculture and Veterinary graduates directly. (Britannia, Lay's, OMFED, Patanjali, GMG Bio herbs, other fertiliser, pesticidesand veterinary medicine companies etc.) No linkage through campus interviews or specialised course works are there.

Though we study agriculture subject as a technical course but There is a lacunae of linkage between field application and theory. The RAWE (Rural Agriculture Work Experience) a practical course work of six months for B.Sc. (Agriculture) courses is implemented during last semester. After which the students get post-graduation only in their specialised courses. So we have less opportunities to gain practical knowledge. Unlike South India industrialisation of agriculture in Odisha is yet to flourish. Cost-effective solutions are needed for machineries, land and labour.as agriculture sector generally lacks high value customers.

\section{Wastage of years}

Students felt that if they start making entrepreneurship in youth stage then they will lose years in terms of age. But age as a factor plays role as an eligibility criteria for Government jobs and also to some extent in Private jobs. (mostly for general category candidates). Therefore entrepreneurship becomes a secondary option with lesser devotion. They will normally prefer good jobs as academician or bankers as safe options rather than to be entrepreneurs.

\section{Marketing strategy}

According to them, though OUAT students do study agricultural economics as a major subject here, still agricultural marketing has still not evolved as a part of it. Students from Management background excel in marketing skills as their approach towards this is very specific. Again almost every private and semi-Government sectors are hiring marketing professionals for expansion of business. A different outlook is needed for marketing strategies on agriculture. Experts need to focus here for development of quality entrepreneurship units.

\section{Losing of good opportunities relating to career}

Relating to future aspects, with view of good careers as OUAT students, they may get some lucrative job opportunities after higher studies. Again due to modest family backgrounds, options are worth choosing for them. And after settling with a good job profiles, entrepreneurship may become a distant dream for them.

\section{Labour cost}

Labour problem has emerged as another issue in agriculture sector now. Due to livelihood in-securities in agriculture as seasonal unemployment, less labour wages and MNREGA being another valid option for them people have lost interest to become agricultural labourers. Therefore labour cost has raised considerably.Its also posing threat for entrepreneurship making.

\section{Frequency Table Analysis Strength}

From the above data it is evident that Rural Agriculture Work Experience is showing that maximum amount of frequency and percentage (82\%) as strength factor. So it is playing a good role for them. Other factors like selected through entrance exam (62\%), Understanding the latest issues of agriculture (66\%), Practical feasibility of many courses (42\%) are also playing good role as strength.

\section{Weakness}

Amongst the Weakness factors Less emphasis on entreprenurship in course curriculum ( $82 \%)$, Cultural effect $(84 \%)$, Orientation of society towards job security $(80 \%)$ etc are playing major role while Theoretical course work $(70 \%)$, Capital (66\%), No family back-up (76\%) are also very important factors. In comparison to other factors Interested only in partnership projects \& Lacking risk taking ability and faith $(42 \%)$ is not pronounced very much as compared to others as a weakness factor.

\section{Opportunity}

Here inflation \& existing demand $(82 \%)$ is playing a major role here as an opportunistic factor while Credit scheme towards agriculture graduates (64\%), Easy decision and finance making $(66 \%)$ and Micro-enterprises as initiatives/Home stead production units related to agriculture and are also important ones. Govt schemes suitability \& Promotion of entrepreneurship projects in agriculture (40\%) and Expert Advice (46\%) and Expert Advice (46\%) a lso do have some role.

\section{Threat}

Financial crisis (Fund/ Credit) $(78 \%)$ is a major threat factor here. Marketing strategy $(72 \%)$ and Wastage of years \& Losing of good opportunities relating to career (66\%), Labour cost $(62 \%)$, Technological lacunae $(62 \%)$ are also quite influencing factors of threat.

Table 1: Swot Analysis

\begin{tabular}{|c|c|}
\hline Internal & External \\
\hline $\begin{array}{l}\text { Strengths (S) } \\
\text { competitive advantage to the business } \\
\text { - } \quad \text { Rural Agricultural Work Experience } \\
\text { - } \quad \text { Selected through Entrance Exam } \\
\text { - } \quad \text { Understanding the latest issues of agriculture } \\
\text { - } \quad \text { Practical feasibility of many course }\end{array}$ & $\begin{array}{l}\text { Opportunities }(\mathbf{O}) \\
\text { strengthen competitive advantage of the business } \\
\text { - } \quad \text { Govt schemes suitability \& Promotion of entrepreneurship projects in } \\
\text { agriculture } \\
\text { - } \quad \text { Micro-enterprises as initiatives / Home stead production units related to } \\
\text { agriculture } \\
\text { - } \quad \text { Inflation \& existing demand } \\
\text { - } \quad \text { Easy decision and finance making } \\
\text { - } \quad \text { Expert Advice }\end{array}$ \\
\hline $\begin{array}{l}\text { Weaknesses }(\mathbf{W}) \\
\text { factors that weaken competitiveness } \\
\text { - Theoritical course work } \\
\text { - } \quad \text { Less emphasis on entreprenurship in course curriculum }\end{array}$ & $\begin{array}{l}\text { Threats (T) } \\
\text { create problems for the business } \\
\text { - } \quad \text { Financial crisis( Fund/ Credit) } \\
\text { - } \quad \text { Technological lacunae } \\
\end{array}$ \\
\hline
\end{tabular}


- Capital

- Orienatation of society towards job security

- No family back-up

- Cultural effect

- Interested only in partnership projects \& lacking risk taking ability and faith
- Wastage of years \& Losing of good opportunities relating to career

- Marketing strategy

- Labour cost

Table 2: Socio-economic Background of students

$(\mathrm{N}=50)$

\begin{tabular}{|c|c|c|c|c|c|c|c|c|c|c|c|}
\hline \multirow{3}{*}{ Students' } & \multicolumn{2}{|c|}{ Educational Qualification } & \multicolumn{5}{|c|}{ Family Background } & \multicolumn{2}{|c|}{ Family type } & \multicolumn{2}{|c|}{$\begin{array}{l}\text { Average annual } \\
\text { income }\end{array}$} \\
\hline & \multirow[t]{2}{*}{$\begin{array}{c}\text { MSc. } \\
\text { (Agri/ Vet) }\end{array}$} & \multirow[t]{2}{*}{$\begin{array}{c}\text { PhD } \\
\text { (Agri/Vet) }\end{array}$} & \multicolumn{2}{|c|}{$\begin{array}{c}\text { No. of members } \\
\text { who earn in family }\end{array}$} & \multicolumn{3}{|c|}{ Father's occupation } & \multirow[t]{2}{*}{$\begin{array}{l}\text { Nuclear } \\
\text { family }\end{array}$} & \multirow[t]{2}{*}{$\begin{array}{c}\text { Joint } \\
\text { family }\end{array}$} & \multirow[t]{2}{*}{$\begin{array}{l}\text { Within 5- } \\
10 \text { lakhs }\end{array}$} & \multirow[t]{2}{*}{$\begin{array}{c}\text { More than } \\
10 \text { lakhs }\end{array}$} \\
\hline & & & one & $\begin{array}{l}\text { More than } \\
\text { one }\end{array}$ & $\begin{array}{l}\text { Govt. } \\
\text { job }\end{array}$ & $\begin{array}{l}\text { Pvt. } \\
\text { job }\end{array}$ & Farming/business & & & & \\
\hline \begin{tabular}{|l|} 
Frequency(f) \\
\end{tabular} & 27 & 23 & 34 & 16 & 23 & 13 & 14 & 33 & 17 & 38 & 12 \\
\hline$\%$ & 58 & 46 & 68 & 32 & 46 & 26 & 28 & 66 & 34 & 76 & 24 \\
\hline
\end{tabular}

Table 3: Frequency \& Percentage Distribution Table of SWOT Analysis (N=50)

\begin{tabular}{|c|c|c|c|c|c|c|c|c|c|c|c|}
\hline \multicolumn{3}{|l|}{ Strength } & \multicolumn{3}{|l|}{ Weakness } & \multicolumn{3}{|l|}{ Opportunity } & \multicolumn{3}{|l|}{ Threat } \\
\hline Factors & f & $\%$ & Factors & f & $\%$ & Factors & f & $\%$ & Factors & f & $\%$ \\
\hline \multirow{2}{*}{$\begin{array}{l}\text { Rural Agricultural } \\
\text { Work Experience }\end{array}$} & \multirow[t]{2}{*}{41} & \multirow[t]{2}{*}{82} & Theoritical course work & 35 & 70 & $\begin{array}{l}\text { Govt schemes suitability } \\
\& \text { Promotion of } \\
\text { entrepreneurship projects } \\
\text { in agriculture }\end{array}$ & 20 & 40 & $\begin{array}{l}\text { Financial crisis } \\
\text { (Fund/ Credit) }\end{array}$ & 39 & 78 \\
\hline & & & $\begin{array}{l}\text { Less emphasis on } \\
\text { entreprenurship in } \\
\text { course curriculum }\end{array}$ & 41 & 82 & \multirow{2}{*}{$\begin{array}{c}\text { Micro-enterprises as } \\
\text { initiatives/ Home stead } \\
\text { production units related to } \\
\text { agriculture } \\
\end{array}$} & \multirow[t]{2}{*}{29} & \multirow[t]{2}{*}{58} & \multirow[t]{2}{*}{$\begin{array}{l}\text { Technological } \\
\text { lacunae }\end{array}$} & \multirow[t]{2}{*}{28} & \multirow[t]{2}{*}{56} \\
\hline \multirow[b]{2}{*}{$\begin{array}{l}\text { Selected through } \\
\text { Entrance Exam }\end{array}$} & \multirow[b]{2}{*}{31} & \multirow[b]{2}{*}{62} & Capital & 33 & 66 & & & & & & \\
\hline & & & $\begin{array}{l}\text { Orienatation of society } \\
\text { towards job security }\end{array}$ & 40 & 80 & \multirow[t]{2}{*}{$\begin{array}{l}\text { Credit scheme towards } \\
\text { agriculture graduates }\end{array}$} & \multirow[t]{2}{*}{32} & \multirow[t]{2}{*}{64} & $\begin{array}{l}\text { Wastage of years \& } \\
\text { Losing of good } \\
\text { opportunities relating } \\
\text { to career }\end{array}$ & 33 & 66 \\
\hline \multirow{2}{*}{$\begin{array}{l}\text { Understanding the } \\
\text { latest issues of } \\
\text { agriculture }\end{array}$} & \multirow[b]{2}{*}{33} & \multirow[b]{2}{*}{66} & No family back-up & 36 & 76 & & & & \multirow[b]{2}{*}{ Marketing strategy } & \multirow[b]{2}{*}{36} & \multirow[b]{2}{*}{72} \\
\hline & & & Cultural effect & 42 & 84 & $\begin{array}{c}\text { Inflation \& existing } \\
\text { demand }\end{array}$ & 41 & 82 & & & \\
\hline \multirow{2}{*}{$\begin{array}{c}\text { Practical } \\
\text { feasibility of many } \\
\text { courses }\end{array}$} & \multirow{2}{*}{21} & \multirow{2}{*}{42} & \multirow{2}{*}{$\begin{array}{l}\text { Interested only in } \\
\text { partnership projects \& } \\
\text { Lacking risk taking } \\
\text { ability and faith }\end{array}$} & \multirow{2}{*}{21} & \multirow{2}{*}{42} & $\begin{array}{c}\text { Easy decision and finance } \\
\text { making }\end{array}$ & 33 & 66 & \multirow{2}{*}{ Labour cost } & \multirow{2}{*}{31} & \multirow{2}{*}{62} \\
\hline & & & & & & Expert Advice & 23 & 46 & & & \\
\hline
\end{tabular}

\section{Conclusion}

From this study we found some Strength and Opportunity factors and many Threat and Weakness factors. For strategical development of farm entrepreneurship we need to mitigate the negative factors. Some are sociological and psychological factors which need awareness and long term planning to combat. Rather through discussion and analysis we generated some views and ideas.

Some opinions are that students here do acquire knowledge and skill with varied options to apply their knowledge for earning livelihood. But due to not owning land, labour and capital they normally don't go for it. They are fascinated by success stories of Steve Jobs, Mark Jukerberg, Ambani Brothers and other successful entrepreneurs of other fields. But they hardly find any entrepreneur giant from OUAT background to follow their foot steps. Still many successful entrepreneurs are there in these fields (e.g. Nutricrafts) but they are yet to be in limelight. And if at all they are successful they are not cherished as entrepreneur ship tycoons. Students do aspire for civil services, research services etc. and prefer to take risk with preparation for years but they rarely think for a small entrepreneurship unit with less investments from early ages. Entrepreneurship may not look prestigious initially but if properly taken care of it may bloom to bigger networks gradually.
Another aspect is that jobs are definitely shrinking due to high competition status with emerging population. So entrepreneurship may play a big role for income generation. But it needs a strong base with strong government support. Again if permitted by reputed farms then franchisee farms can also become another option with skilled individuals as partners. So that risk factor can be mitigated.

\section{References}

1. Farr-Wharton R, Brunetto Y. Female entrepreneurs as managers: The role of social capital in facilitating a learning culture. Gender in Management: An International Journal. 2009; 24(1):14-31.

2. Fornell C, Larcker DF. Evaluating structural equation models with unobservable variables and measurement error. Journal of Marketing Research, 1981; 48:39-50.

3. Gaglio CM, Katz JA. The psychological basis of opportunity identification: Entrepreneurial alertness. Small Business Economics. 2001; 16:95-111.

4. Fornell C, Larcker DF. Evaluating structural equation models with unobservable variables and measurement error. Journal of Marketing Research. 1981; 48:39-50.

5. Gaglio CM, Katz JA. The psychological basis of opportunity identification: Entrepreneurial alertness. Small Business Economics. 2001; 16:95-111. 
6. Guthrie MJD. The Rural Youth Entrepreneur Project, An Unpublished M.Sc.(Ag.) Thesis submitted to the Faculty of Department of Agricultural Education at the University of Arizona, Tucson, 2013.

7. Hajong, Deepika. A Study on Agrientrepreneurship Behavior among Farmers, Unpublished Ph.D. Thesis submitted to Division of Extension Education, Indian Agricultural Research Institute, New Delhi, 2014.

8. Napitupulu EL. (2012, October 23rd). Mahasiswa Masih Terbelenggu Mencari Kerja. Retrieved From http://edukasi.kompas.com/read/2012/10/23/1754510/Ma hasiswa.Masih.Terbelenggu.Mencari.KerjaEntrepreneurs hip Learning Process by using SWOT Analysis (PDF Download Available). Available from: https:/www.researchgate.net/publication/318986368_Ent repreneurship_Learning_Process_by_using_SWOT_Anal ysis 